\title{
EVALUASI MODEL BISNIS PADA LAUNDRY BAR DENGAN PENDEKATAN BUSINESS MODEL CANVAS
}

Mediany Kriseka Putri ${ }^{1}$, Angga Dwi Utama ${ }^{2}$

Creative Industry Faculty,Telkom University

Economy and Business Faculty,Telkom University

mediany.kris@gmail.com ${ }^{1}$, anggadwiutama@gmail.com ${ }^{2}$

\begin{abstract}
Abstrak
Tujuan dilakukannya penelitian ini adalah untuk menganalisis dan mengevaluasi penerapan model bisnis pada Laundry Bar sebagai bisnis yang dapat dikatakan baru. Teori yang digunakan dalam penelitian ini adalah teori business model canvas. Metode yang digunakan dalam penelitian ini bersifat deskriptif dan tipe analisis yang digunakan pada penelitian ini adalah analisis kualitatif dengan menggunakan in-depth interview dalam mengumpulkan data primer yang dibutuhkan pada penelitian. Hasil dari penelitian ini adalah berupa evaluasi model bisnis Laundry Bar berdasarkan analisis SWOT pada setiap elemen business model canvas yang sudah dilakukan untuk lebih memperhatikan kualitas layanan dan tidak lagi berfokus pada minimasi biaya seperti sebelumnya sehingga struktur biaya bisnis juga berubah dari cost-driven menjadi value-driven. Diharapkan dengan dilakukannya evaluasi model bisnis melalui penelitian ini, hasilnya dapat bermanfaat bagi perkembangan dan keberlangsungan bisnis Laundry Bar kedepannya.
\end{abstract}

\section{Kata Kunci: Kewirausahaan; Model Bisnis; Bisnis Model Kanvas}

\section{Abstract}

The purpose of this research is to analyze and evaluate the implementation of business model on Laundry Bar as a new business. The theories used in this research is the theory of business model canvas and SWOT analysis. This research is using descriptive method and the type of analysis used in this research is qualitative analysis by using in-depth interviews to collect primary data that required in this research. The output from this research is the evaluation from Laundry Bar's business model based on the SWOT analysis of each element of the business model canvas. The evaluation is for giving more attention to service quality and not focused on cost minimization anymore. Thus, the business cost structure could change from cost-driven into value-driven. As expected, with this evaluation of business model through this research, the results can be useful for Laundry Bar's business development and sustainability in the future.

Keywords: Entrepreneurship; Business Model; Business Model Canvas

\section{Pendahuluan}

Laundry Bar merupakan usaha laundry yang berada di sekitar kawasan Universitas Telkom dan masih bisa dikatakan baru berjalan, karena usaha ini baru berdiri pada tanggal 20 Mei 2015, kondisi persaingan penyedia jasa laundry di kawasan Universitas Telkom yang cukup tinggi menuntut Laundry Bar untuk terus meningkatkan kapabilitas dari bisnisnya agar dapat terus bertahan dan unggul dari para pesaingnya, di antaranya adalah Seven Laundry dan Liquid yang juga berada di kawasan Universitas Telkom. Agar usaha dapat berjalan dengan baik dan sukses tentunya tidak hanya dibutuhkan kreatifitas saja, ilmu dan pengetahuan yang luas serta kemampuan tata kelola yang baik merupakan faktor penting yang bisa menjadi bekal untuk mengembangkan bisnis yang telah dijalankan maupun yang masih baru.

Salah satu kemampuan tata kelola yang harus dimiliki adalah dalam hal penerapan model bisnis yang menjadi konsep dasar untuk mengembangkan suatu bisnis, maka dari itu perlu dilakukan analisis terhadap Laundry Bar untuk mengetahui seperti apakah bisnis model yang diterapkan bisnis tersebut. Model bisnis merupakan salah satu faktor yang dapat 


\section{JURNAL \\ MANAJEMEN \\ INDONESIA}

Vol. 17 - No. 2

Agustus 2017

Gambar 1.

Grafik Pendapatan dan

Keuntungan Laundry

Bar

Sumber:

Laundry Bar, 2015 mempengaruhi kinerja suatu bisnis dan merupakan kunci suatu bisnis untuk meningkatkan daya saing dan mencapai tujuannya, model bisnis adalah suatu model yang memberikan penjelasan mengenai bagaimana suatu bisnis mendapatkan atau mencapai keuntungan dan siapa pelanggan usaha tersebut. Dari paparan di atas dapat terlihat bahwa peran model bisnis sangatlah vital dalam menentukan keberlangsungan hidup suatu bisnis (www.pupuk.or.id, 2012). Salah satu alat yang sering digunakan untuk menilai suatu model bisnis adalah Business Model Canvas karena telah sering memberikan kontribusi terhadap penggunaan model bisnis pada suatu organisasi. Business Model Canvas lebih difokuskan pada pelaksanaan sebuah ide untuk menciptakan nilai pada suatu organisasi (Coes, 2014:3).

Selain itu, cara lain yang dapat digunakan untuk menilai kinerja atau kemampuan suatu bisnis adalah dengan melihat pendapatan dan keuntungan dari bisnis yang dijalankan dalam periode waktu tertentu. Pada gambar berikut dapat dilihat jumlah pendapatan dan keuntungan Laundry Bar dalam beberapa bulan terakhir.

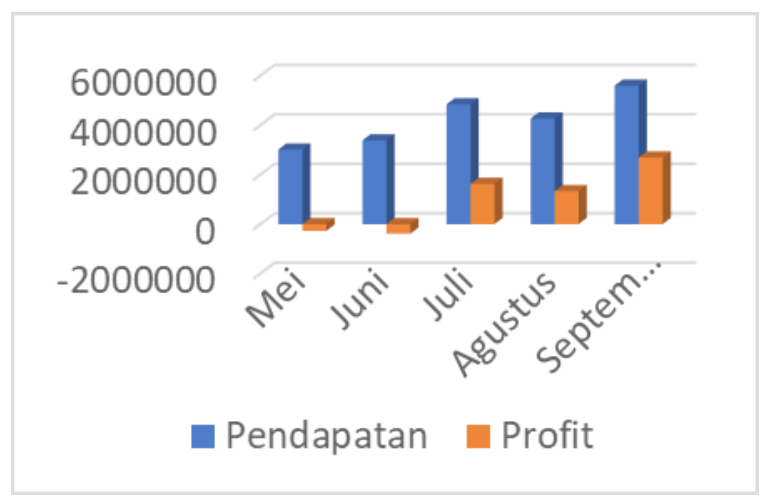

Dari gambar di atas dapat terlihat bahwa pendapatan dan keuntungan Laundry Bar masih fluktuatif dan pada bulan Juni terlihat walaupun pendapatan dari Laundry Bar meningkat, namun profit yang diperoleh cenderung menurun. Dari data di atas yang fluktuatif juga dapat dikatakan bahwa Laundry Bar perlu meningkatkan kemampuan tata kelolanya agar kedepannya kinerja bisnis ini dapat terus berkembang stabil.

Berdasarkan latar belakang di atas dan juga permintaan dari Bapak Andi Muhammad Yusuf Pratama selaku pemilik bisnis Laundry Bar yang bermaksud untuk meningkatkan kemampuan tata kelola usahanya demi mengembangkan usaha Laundry Bar di masa mendatang, maka melalui evaluasi yang dilakukan diharapkan terdapat manfaat yang dapat diperoleh untuk kelangsungan bisnis dan pengembangan bisnis Laundry Bar kedepannya.

\section{Kajian Literatur}

\subsection{Manajemen Strategis}

Manajemen strategis merupakan seperangkat keputusan dan tindakan yang menghasilkan rancangan dan realisasi strategi untuk mencapai tujuan yang dimiliki oleh suatu organisasi. Manajemen strategi pada suatu organisasi merupakan hal yang penting karena menjelaskan rencana yang telah dirancang oleh suatu organisasi untuk meraih tujuan melalui satu set keputusan dan tindakan yang akhirnya akan menghasilkan formulasi dan implementasi dari rencana yang telah dibuat tersebut (Pearce \& Robinson, 2008:3).

\subsection{The Business Model Canvas}

Menurut Osterwalder \& Pigneur (2009:8), business model canvas adalah alat yang digunakan untuk mendeskripsikan, menganalisa, dan merancang model bisnis suatu perusahaan. Business model canvas juga bisa disebut teknik yang dapat membantu dalam merumuskan model bisnis suatu perusahaan atau lebih lebih kompleksnya merupakan proses generik yang dapat membantu dalam merancang model bisnis yang inovatif bagi perusahaan (Osterwalder \& Pigneur, 2009:14).

Sedangkan bisnis model sendiri adalah gambaran atau penjelasan mengenai bagaimana 
suatu bisnis menciptakan, menangkap, dan memberikan nilai kepada konsumen atau pelanggannya (Osterwalder \& Pigneur, 2009:14). Melalui sembilan blok bangunan dasar (The 9 building blocks) yang meliputi empat bidang utama bisnis, yaitu pelanggan, nilai yang ditawarkan perusahaan, infrastruktur, dan kemampuan finansial, model bisnis suatu perusahaan dapat digambarkan, ini menjelaskan logika bagaimana suatu bisnis meraih keuntungan atau laba (Osterwalder \& Pigneur, 2009:15). Berikut ini adalah penjelasan mengenai The 9 building blocks:

\section{- Customer Segments}

Menurut Osterwalder \& Pigneur (2009:20), customer segments menjelaskan kelompok orang atau organisasi yang dituju, dijangkau, dan dilayani oleh perusahaan. Tanpa memperhatikan pelanggan suatu bisnis tidak akan dapat bertahan lama, oleh karena itu pelanggan merupakan inti dari setiap model bisnis. Suatu perusahaan harus dapat memutuskan tentang segmen yang akan dituju serta dilayani dan segmen yang akan mereka abaikan dengan mengelompokkan pelanggannya ke dalam segmen yang berbeda berdasarkan kebutuhan umum, perilaku umum, atau atribut lainnya.

\section{- Value Propositions}

Menurut Osterwalder \& Pigneur (2009:22) value propositions menggambarkan nilai yang ditawarkan oleh perusahaan kepada segmen pelanggan tertentu melalui produk dan layanannya sehingga menjadi alasan pelanggan memilih suatu perusahaan dibandingkan perusahaan lainnya, nilai yang ditawarkan dapat bersifat kuantitatif (misalnya harga, kecepatan pelayanan) atau kualitatif (misalnya desain, pengalaman pelanggan).

\section{- Channels}

Menurut Osterwalder \& Pigneur (2009:26), saluran menggambarkan cara perusahaan berkomunikasi dan mencapai segmen pelanggan yang dituju, saluran memiliki peran penting dalam meningkatkan kesadaran pada pelanggan terkait produk dan layanan yang ditawarkan perusahaan, menyampaikan dan mengevaluasi proposisi nilai yang ditawarkan perusahaan, dan memberikan akses pada pelanggan untuk membeli produk dan jasa yang ditawarkan.

Saluran dapat dibedakan menjadi saluran langsung dan tidak langsung serta saluran sendiri dan mitra, saluran yang dimiliki perusahaan dapat bersifat langsung, seperti melalui situs web dan tenaga penjualan yang dimiliki, atau tidak langsung, seperti toko retail yang dioperasikan dan dimiliki oleh perusahaan. Saluran mitra yang tidak langsung juga dapat memberikan kemudahan bagi perusahaan dalam menjangkau pelanggan melalui berbagai pilihan saluran, seperti distribusi grosir, situs web retail, dan atau mitra lainnya.

\section{- Customer Relationships}

Customer relationship menjelaskan bagaimana suatu perusahaan menciptakan dan memelihara hubungan dengan segmen pelanggan yang dituju. Motivasi perusahaan dalam membangun hubungan pelanggan diantaranya adalah untuk akuisisi pelanggan, retensi pelanggan, ataupun untuk meningkatkan penjualan (upselling) (Osterwalder \& Pigneur, 2009:28).

\section{- Revenue Streams}

Menurut Osterwalder \& Pigneur (2009:30), revenue streams atau aliran pendapatan merepresentasikan kas perusahaan yang dihasilkan dari setiap segman pelanggan. Suatu model bisnis dapat melibatkan dua jenis aliran pendapatan, yaitu pendapatan transaksi yang dihasilkan dari one-time customer payments dan pendapatan yang berkelanjutan atau berulang yang dihasilkan dengan memberikan proposisi nilai pada pelanggan maupun menyediakan dukungan post-purchase bagi pelanggan. Beberapa cara yang dapat dilakukan untuk meraih pendapatan adalah melalui penjualan, usage fee (berdasarkan layanan yang digunakan, seperti pada hotel atau perusahaan telekomunikasi), Subscription, Lending/Renting/ Leasing (memberikan hak untuk menggunakan asset tertentu), dan Licensing (Memberikan pelanggan untuk menggunakan kekayaan intelektual yang dimiliki).

\section{- Key Resources}

JURNAL

MANAJEMEN

INDONESIA

Vol. 17 - No. 2

Agustus 2017 


\section{JURNAL}

MANAJEMEN INDONESIA

Vol. 17 - No. 2

Agustus 2017

Key resources merupakan aset penting yang dibutuhkan perusahaan untuk menciptakan nilai bagi pelanggan, mencapai pasar dan segmen yang dituju, menjaga hubungan dengan segmen pelanggan, meraih keuntungan, serta mendukung suatu bisnis agar tetap bekerja. Key resources dapat dimiliki oleh perusahaan atau disewa dan diperoleh dari mitra bisnis, key resources dapat berbentuk fisik, keuangan atau finansial, intelektual atau pengetahuan, dan manusia (Osterwalder \& Pigneur, 2009:34).

\section{- Key Activities}

Key activities merupakan kegiatan penting yang harus dilakukan perusahaan untuk membuat bisnis tetap berjalan, termasuk di dalamnya menawarkan proposisi nilai menjangkau pasar, mempertahankan hubungan pelanggan, dan meraih keuntungan. Key activities dapat dikategorikan ke dalam produksi, pemecahan masalah, dan platform/jaringan layanan dan promosi (Osterwalder \& Pigneur, 2009:36).

\section{- Key Partners}

Menurut Osterwalder \& Pigneur (2009:38), Key partners menggambarkan jaringan pemasok dan mitra yang berhubungan dengan perusahaan. Suatu perusahaan menjalin kemitraan untuk banyak alasan diantaranya untuk mengoptimalkan model bisnis mereka, mengurangi risiko, atau memperoleh sumber daya. Kemitraan dapat dibagi kedalam empat jenis, yaitu aliansi strategis antara non-pesaing, koperasi yang terdiri dari kemitraan strategis antara pesaing, usaha patungan untuk mengembangkan bisnis baru, dan hubungan pembelipemasok untuk menjamin pasokan bahan produksi yang dibutuhkan.

\section{- Cost Structure}

Menurut Osterwalder \& Pigneur (2009:40), Struktur biaya menjelaskan seluruh biaya yang dikeluarkan dalam mengoperasikan suatu model bisnis, termasuk di dalamnya kegiatan menciptakan dan memberikan nilai kepada pelanggan, menjaga hubungan pelanggan, dan meraih keuntungan atau pendapatan. Struktur biaya dapat dibedakan menjadi dua kelas luas dalam model bisnis, yang pertama adalah cost-driven yang memfokuskan pada minimasi biaya seminimal mungkin dengan tujuan menciptakan dan menjaga struktur biaya yang paling ramping, menggunakan proposisi nilai harga yang rendah, dan outsourchingi yang luas. Dan yang kedua adalah value-driven dimana model bisnis ini berfokus ada penciptaan nilai guna memiliki proposisi nilai yang tergolong premium dan layanan pribadi tingkat tinggi.

\subsection{Analisis SWOT}

Analisis SWOT adalah kegiatan mengamati lingkungan pemasaran internal maupun eksternal melalui evaluasi tentang kekuatan, kelemahan, peluang, dan ancaman perusahaan. Melalui analisis SWOT (Strengths, Weaknesses, Opportunities, Threats) suatu bisnis dapat menelusuri trend, perkembangan penting dan semua peluang maupun ancaman yang memiliki hubungan dengan bisnis dan mempengaruhi kemampuan bisnis dalam meraih keuntungan dengan mengetahui kekuatan lingkungan makro yang utama dan lingkungan mikro yang signifikan (Kotler \& Keller, 2009:51).

Menurut Pearce dan Robinson (2008:200), analisis SWOT merupakan teknik historis untuk menciptakan gambaran umum terkait situasi strategis perusahaan secara cepat. Kekuatan (Strengths) merupakan sumber daya atau kapabilitas dan kompetensi yang dimiliki oleh perusahaan dan membuat perusahaan relatif lebih unggul dalam memenuhi kebutuhan pelanggan dibandingkan pesaingnya. Kelemahan (Weaknesses) merupakan keterbatasan atau kekurangan terkait sumber daya atau kapabilitas yang dimiliki perusahaan dan menjadi hambatan bagi perusahaan dalam memenuhi kebutuhan pelanggannya. Peluang (Opportunities) merupakan situasi utama dari lingkungan suatu perusahaan yang dapat atau mungkin memberikan keuntungan bagi perusahaan, contohnya seperti tren, segmen pasar yang sebelumnya terlewatkan, dan lainnya. Ancaman (Threats) merupakan situasi utama dari lingkungan suatu perusahaan yang tidak menguntungkan bagi perusahaan dan mungkin menjadi penghalang bagi perusahaan dalam mencapai posisi perusahaan saat ini ataupun yang diinginkan perusahaan ke depannya.

\section{Metodologi Penelitian}


Desain penelitian yang digunakan pada penelitian ini adalah deskriptif dengan metode penelitian kualitatif. Menurut Indrawati (2015:115) penelitian deskriptif dilakukan untuk menggambarkan karakteristik dari suatu kelompok yang diteliti dalam situasi tertentu, penelitian deskriptif biasanya dilakukan saat peneliti telah mengetahui variabel yang digunakan untuk mengukur suatu objek dan peneliti hanya menggambarkanvariabel tersebut tanpa melakukan tes hubungan atau pengaruh antar variabel ${ }^{[4]}$. Sedangkan menurut Sugiyono (2014:209) penelitian deskriptif dilakukan untuk mengeksplorasi dan atau menjelaskan situasi sosial yang akan diteliti.

Menurut Sugiyono (2014:8) penelitian kualitatif adalah penelitian yang dilakukan pada kondisi yang alamiah atau berkembang apa adanya dan tidak dimanipulasi oleh peneliti dan kehadiran peneliti tidak mempengaruhi dinamika pada objek yang diteliti, penelitian kualitatif memandang realitas sosial sebagai sesuatu yang utuh dan dinamis. Menurut Somantri (Indrawati, 2015:207) penelitian kualitatif dilakukan untuk mengkonstruksi realitas dan memahami maknanya sehingga penelitian kualitatif biasanya memperhatikan proses, peristiwa, dan otentisitas (asli, dapat dipercaya).Penilitian kualitatif dilakukan untuk memahami dan menginterpretasikan interaksi sosial (Indrawati, 2015:208).

Demikian juga pada penelitian ini peneliti bermaksud untuk mengungkapkan gambaran bisnis model Laundry Bar dan hasil evaluasi bisnis model bisnis tersebut setelah dilakukan analisis SWOT.

\section{Hasil dan Pembahasan}

Berdasarkan penelitian yang telah dilakukan dapat terlihat bahwa usaha Laundry Bar telah menerapkan konsep model bisnis dalam usahanya yang dalam penelitian ini dinilai menggunakan pendekatan Business model canvas. Namun dalam penerapan business model canvas pada usaha Laundry Bar, perlu ada beberapa aspek yang dievaluasi berdasarkan hasil analisis SWOT usaha Laundry Bar yang telah dilakukan, berikut ini adalah pembahasan dari hasil penelitian yang telah dilakukan:

\subsection{Customer Segments}

Laundry Bar memiliki segmen pasar masyarakat umum yang berada di kawasan Universitas Telkom atau khususnya adalah rumah tangga (keluarga) dan mahasiswa. Dengan melihat hasil analisis SWOT yang menjelaskan bahwa Laundry Bar memiliki kekuatan dengan memilih segmen ini, yaitu memiliki pasar yang luas di kawasan Universitas Telkom. Namun terdapat kelemahan yang perlu dipikirkan juga, yaitu Laundry Bar lebih sulit untuk melihat kebutuhan dan keinginan segmennya karena terlalu umum atau kurang spesifik. Selain itu, dengan melihat peluang terdapat permintaan yang tinggi dari mahasiswa Universitas Telkom dan juga mayoritas pelanggan Laundry Bar selama bisnis berjalan adalah mahasiswa serta lokasi bisnis yang berada di kawasan Perguruan Tinggi Universitas Telkom. Ancaman juga datang dari pesaing Laundry Bar yang juga memperebutkan pangsa pasar utama bisnis laundry di kawasan Universitas Telkom. Berdasarkan hal tersebut maka sebaiknya bisnis Laundry Bar lebih fokus untuk melayani mahasiswa atau menetapkan segmen pasarnya mahasiswa Universitas Telkom saja, karena dengan lebih fokus terhadap segmen pasar tertentu usaha Laundry Bar diharapkan dapat melihat keinginan dan kebutuhan spesifik dari segmen tersebut sehingga pangsa pasar utama di kawasan Universitas Telkom, yitu mahasiswa pun akan terpuaskan dan peluang akan tingginya permintaan laundry di kalangan mahasiswa pun dapat dimaksimalkan.

\subsection{Value Propositions}

Jika dikaitkan dengan teori business model canvas pada bab 2, usaha Laundry Bar telah memenuhi sebagian besar elemen-elemen yang berkontribusi dalam menciptakan nilai pelanggan, di antaranya:

a) Newness, elemen ini terlihat dari layanan-layanan yang diberikan oleh Laundry Bar kepada pelanggannya. Laundry Bar memiliki layanan express dimana Laundry lain belum ada yang menerapkan layanan ini, yaitu cuci pakaian atau sepatu yang akan selesai dalam waktu 4-8 jam saja, layanan lain yang diberikan adalah layanan antar jemput laundry 
tanpa ada minimal transaksi maupun batasan waktu yang ditentukan.

\section{JURNAL}

MANAJEMEN

INDONESIA

Vol. 17 - No. 2

Agustus 2017 b) Performance, elemen ini terlihat dari layanan fast (24 jam selesai) dan express (selesai di hari yang sama, 4-8 jam) yang ditawarkan Laundry Bar, peningkatan kinerja layanan tersebut tentunya dapat memberikan kepuasan bagi pelanggan yang memiliki kesibukan dan harus menggunakan pakaian tertentu yang harus dicuci terlebih dahulu. Hal ini juga tentunya mampu memberikan nilai bagi pelanggan Laundry Bar.

c) Costumization, elemen ini terlihat dari pilihan layanan Laundry Bar regular, fast, dan express yang dapat dipilih sesuai kebutuhan pelanggan Laundry Bar. Selain itu, perlakuan khusus yang diberikan terhadap pakaian tertentu, seperti pakaian putih dan pakaian luntur sesuai permintaan konsumen tentunya dapat menjawab kebutuhan spesifik pelanggan Laundry Bar. Layanan setrika saja dan atau cuci saja juga ditawarkan bagi pelanggan Laundry Bar yang hanya membutuhkan jasa cuci dan atau setrika saja.

d) "Getting the job done", elemen ini terlihat dari kemudahan yang diberikan oleh Laundry Bar kepada pelanggannya dalam menyelesaikan pekerjaan mencuci dan setrika pakaian, karpet, sepatu, dan boneka.

e) Price, elemen ini terlihat dari harga yang ditawarkan Laundry Bar yang cukup bersaing, yaitu Rp 5000,- per1 kilogram cucian. Selain itu, program membership yang dimiliki Laundry Bar juga memberikan keuntungan potongan 2-3 kg cucian bagi member Laundry Bar.

f) Risk Reduction, hal ini terlihat dari pemberian jaminan dari kualitas layanan yang diberikan. Laundry Bar memberlakukan layanan complain maksimal 2x24 jam setelah cucian diterima konsumen. Hal ini memperkecil risiko kehilangan pakaian bagi pelanggan dan juga risiko pakaian yang kurang bersih atau terkena lunturan, karena pakaian tersebut akan dicuci kembali hingga bersih atau lunturan pada pakaian hilang. Selain itu Bapak Andi Muhammad Yusuf juga terkadang melakukan inspeksi terhadap pakaian yang sedang dijemur dan dipilah jika masih kurang bersih.

g) Accesibility, hal ini terlihat dari tersedianya layanan antar jemput cucian dan adanya store Laundry Bar di Jalan Sukapura No. 39 B (depan SMA Negeri 1 Dayeuh Kolot) yang berada di kawasan Universitas Telkom yang memberikan kemudahan bagi pelanggannya dalam mendapatkan layanan.

h) Convenience/usability, hal ini terlihat dari penggunaan media sosial Line@ oleh Laundry Bar yang memberikan rasa nyaman dan kemudahan dalam memberikan saran ataupun memesan layanan antar jemput Laundry Bar.

Berdasarkan analisis SWOT yang telah dilakukan, Laundry Bar memiliki kekuatan, yaitu telah menjalankan sebagian besar elemen-elemen yang berkontribusi dalam menciptakan nilai bagi pelanggan dan juga memiliki beragam jenis layanan dan promo yang belum dimiliki bisnis sejenis yang berada di kawasan Universitas Telkom, kelemahan dari Laundry Bar adalah belum terbentuknya citra merek Laundry Bar pada segmen pasar utama bisnis yang terdiri dari mahasiswa Universitas Telkom. Terdapat juga peluang yang dapat dimanfaatkan oleh Laundry Bar, diantaranya permintaan akan layanan cuci Helm terlebih pada musim penghujan, dimana penyedia layanan ini masih sangat jarang terutama di kawasan Universitas Telkom dan tingginya churn ratei pada bisnis laundry di kalangan mahasiswa Universitas Telkom yang juga dapat menjadi peluang sekaligus ancaman bagi Laundry Bar. Selain itu, ancaman juga datang dari pesaing Laundry Bar, yaitu Liquid Laundry dan juga Seven Laundry. Berdasarkan hal tersebut, terdapat beberapa evaluasi pada aspek value propositions yang dimiliki Laundry Bar, hasil dari evaluasi tersebut adalah menyediakan layanan cuci Helm, karena di kawasan Universitas Telkom masih sangat jarang terdapat layanan ini dan adanya kebutuhan dari layanan cuci Helm terlebih pada musim penghujan. Selain itu, dengan melihat kelemahan pada citra merek Laundry Bar karena bisnis yang masih cenderung baru, peningkatan kualitas juga perlu dilakukan dan tidak hanya fokus memberikan harga yang bersaing karena banyak usaha laundry di kawasan Universitas Telkom yang juga memberikan harga yang bersaing, di antaranya adalah Seven Laundry dan Liquid. Dengan adanya peningkatan kualitas, tentunya akan terbentuk citra pada konsumen sehingga pada akhirnya loyalitas konsumen pun akan terbentuk. Selain itu, penambahan promo pun dirasa 
dapat memberikan nilai yang dapat menarik konsumen diantaranya melalui sistem voucher yang dapat diperoleh pada transaksi pertama dan hanya bisa digunakan pada transaksi-transaksi selanjutnya, selain dapat memberikan nilai bagi konsumen dari segi price, hal ini juga dapat menstimulus terjadinya aliran pendapatan yang berulang bagi Laundry Bar.

\subsection{Channels}

Dalam menyampaikan nilai kepada pelanggannya, Laundry Bar menggunakan saluran langsung, yaitu melalui tenaga penjualan atau layanan antar jemput Laundry Bar dan juga secara tidak langsung, yaitu melalui store Laundry Bar yang berada di Jalan Sukapura No. 39 B (depan SMA Negeri 1 Dayeuh Kolot). Selain itu, nilai juga disampaikan sendiri oleh Laundry Bar melalui akun media sosial Line@ yang dimilikinya.

Kekuatan yang dimiliki Laundry Bar adalah terdapat penggunaan media sosial Line@ dan juga telah maksimalnya pemanfaatan saluran yang telah dimiliki, namun terdapat juga kekurangan, yaitu meskipun pemanfaatannya telah maksimal, dirasa masih terlalu sedikit saluran yang dimiliki oleh Laundry Bar, atau dapat dikatakan bisnis laundry pesaing Laundry Bar juga telah memiliki saluran yang sama, yaitu melalui store dan juga layanan antar jemput. Selain itu, Laundry Bar baru memiliki satu store saja dan sering juga terjadi permasalahan over order dan juga masih belum adanya media yang berperan sebagai penyedia informasi bagi pelanggan seputar Laundry Bar yang dapat memberikan info secara lengkap. Peluang yang dimiliki oleh Laundry Bar adalah peluang untuk menjalin kerja sama dengan penyedia jasa kost-kostan atau asrama di Universitas Telkom karena jumlah dari penyedia jasa tersebut cukup banyak dan sangat dekat dengan pelanggan utama, yaitu mahasiswa. Ancaman juga tentunya datang dari pesaing Laundry Bar yang telah memiliki lebih dari satu store, sehingga memiliki kapasitas produksi dan cakupan yang lebih luas dibanding Laundry Bar.

Untuk menambah saluran guna menjangkau konsumen lebih banyak lagi, Laundry Bar dapat bekerja sama dengan kos-kosan sekitar Universitas Telkom maupun asrama yang terdapat pada Universitas Telkom. Untuk mempermudah pelanggan dalam memperoleh informasi seputar bisnis, Laundry Bar dapat membuat website. Selain untuk memberikan informasi seputar bisnis, website tentunya dapat juga digunakan sebagai media promosi dan tempat menyampaikan kritik serta saran.

\subsection{Customer Relationships}

Jika dikaitkan dengan teori yang telah dibahas sebelumnya pada bab 2, maka dalam menjalankan customer relationships, Laundry Bar telah menjalankan 4 dari 6 kategori yang dipaparkan, yaitu:

a) Personal Assistance, yang dijalankan melalui layanan komplain yang disediakan oleh Laundry Bar yang berlaku maksimal 2x24 jam setelah pelanggan menerima cuciannya.

b) Self-service, terlihat dari tersedianya store Laundry Bar sehingga pelanggan dapat datang langsung ke lokasi store yang berada di Jalan Sukapura No. 39 B (depan SMA Negeri 1 Dayeuh Kolot), Kabupaten Bandung.

c) Automated Services, yang dijalankan dengan memberikan rekomendasi terkati layanan yang diberikan dan juga menawarkan serta memberikan informasi berkaitan dengan pesanan atau transaksi, contohnya dengan memberikan catatan pada cucian pelanggan atau melalui media sosial Line@.

d) Co-creation, yang dijalankan dengan meminta review dari pelanggan terkait layanan yang telah diberikan oleh Laundry Bar dan juga meminta masukan pada beberapa pelanggannya dalam hal penambahan layanan yang akan diberikan oleh Laundry Bar.

Kekuatan yang dimiliki Laundry Bar dari sisi customer relationship adalah Laundry Bar telah menjalankan hubungan pelanggan dengan serius dan mampu mengatasi keluhankeluhan pelanggan yang pernah masuk. Laundry Bar juga melibatkan konsumen dalam penciptaan nilai sehingga keinginan dan kebutuhan konsumen dapat terpenuhi melalui nilai yang Laundry Bar tawarkan. Kelemahan yang dimiliki adalah masih minimnya penggunaan media sosial (yang menjadi trend dan banyak digunakan saat ini) untuk menjalin hubungan
JURNAL

MANAJEMEN

INDONESIA

Vol. 17 - No. 2

Agustus 2017

\section{3}




\section{JURNAL}

MANAJEMEN

INDONESIA

Vol. 17 - No. 2

Agustus 2017 dengan pelanggan yang telah ada maupun untuk menarik pelanggan baru, bisnis ini baru menggunakan satu media saja, yaitu Line@. Peluang untuk meningkatkan hubungan pelanggan terlihat dari kebiasaan mahasiswa Universitas Telkom yang merupakan pangsa utama dalam penggunaan media sosial, terlihat dari maraknya penggunaan media sosial di kalangan mahasiswa sebagai tempat bertukar informasi maupun sekedar untuk update. Selain itu, banyaknya bisnis-bisnis yang berada di kawasan Universitas Telkom maupun kota Bandung dapat menjadi peluang tersendiri bagi Laundry Bar untuk menjalin kerja sama atau hubungan yang saling menguntungkan. Ancaman dari segi hubungan pelanggan adalah jika pelanggan tidak terangkul atau terlayani dengan baik makan tingakt churn rate pun akan meningkat, pengaruh word of mouth jika konsumen kecewa dan hubungan pelanggan tidak dilakukan juga akan berdampak negatif bagi Laundry Bar, yaitu hilangnya konsumen dan munculnya persepsi negatif pada konsumen.

Berdasarkan hal tersebut Laundry Bar dapat menggunakan lebih banyak media sosial lagi untuk menjaga hubungan dengan konsumen dan juga untuk menunjukkan kelebihan dari layanan yang diberikan, media sosial juga dapat digunakan untuk memberikan apresiasi bagi pelanggan yang telah terlibat dan membantu Laundry Bar dalam menciptakan nilai, media sosial juga dapat digunakan untuk pencitraan atau menciptakan persepsi positif di kalangan konsumen Laundry Bar. Dengan melihat peluang yang ada juga, Laundry Bar dapat menjalin kerja sama dengan pihak lain dalam meningkatkan fungsi member yang sudah ada, misalnya member Laundry Bar tidak hanya dapat digunakan di Laundry Bar saja, tetapi dapat juga digunakan di merchant-merchant yang bekerja sama dengan Laundry Bar untuk mendapatkan diskon ataupun keuntungan khusus.

\subsection{Revenue Streams}

Aliran pendapatan bisnis Laundry Bar didapatkan dari penjualan layanan cuci dan setrika pakaian, sepatu, boneka, dan karpet yang ditawarkan Laundry Bar serta melalui program membership yang ditawarkan oleh bisnis Laundry Bar. Jika dikaitkan dengan teori pada bab 2, maka aliran pendapatan didapatkan dari usage fee atau berdasarkan layanan yang digunakan, dalam hal ini bergantung pada berat dari cucian dan jenis benda yang diminta untuk dicuci oleh pelanggan. Aliran pendapatan juga didapatkan dari subscription, yaitu melalui program membership yang ditawarkan oleh Laundry Bar.

Jika dikaitkan dengan hasil evaluasi elemen-elemen lain terkait business model canvas Laundry Bar, terdapat beberapa hal yang dapat meningkat pada aliran pendapatan Laundry Bar. Diantaranya program membership yang telah ditambahkan nilainya setelah terjalin kerja sama dengan merchant-merchant lain dan juga terjadinya aliran pendapatan yang berulang melalui sistem voucher yang disarankan untuk diterapkan pada bisnis yang dijalankan Laundry Bar.

\subsection{Key Resources}

Pada bisnis Laudry Bar terdapat nilai-nilai yang diciptakan bagi pelanggan dan dalam menciptakan nilai tersebut tentunya membutuhkan aset-aset penting yang terdiri dari aset fisik, finansial, dan manusia. Aset-aset fisik penting yang dimiliki Laundry Bar di antaranya adalah bangunan store Laundry Bar, mesin cuci, alat setrika, mesin pengering, jemuran dan gantungan pakaian, timbangan, dan rak untuk cucian yang telah selesai. Aset finansial yang dimiliki Laundry Bar adalah kas usaha Laundry Bar sendiri, dan aset lain yang sangat penting adalah sumber daya manusia atau 2 pegawai Laundry Bar yang berperan besar dalam menciptakan nilai bagi pelanggan Laundry Bar.

Berdasarkan hasil analisis SWOT yang telah dilakukan, dimana kekuatan Laundry Bar adalah telah tersedianya sumber daya yang dibutuhkan pada bisnis laundry yang dijalankan dan juga hubungan antar SDM pada Laundry Bar dapat dikatakan cukup dekat sehingga loyalitas pegawai pun dapat terlihat, hal ini tentunya berdampak positif bagi bisnis karena dengan adanya rasa loyal, para pegawai akan turut meperhatikan perkembangan dan keadaan bisnis Laundry Bar. Kelamahan dari segi sumber daya adalah terjadinya over order sebagai akibat dari tidak adanya peningkatan sumber daya yang dapat meningkatkan kapasitas produksi Laundry Bar. Peluang yang dapat diraih Laundry Bar adalah adanya permintaan Laundry di daerah lain di luar Sukapura, seperti PGA, Sukabirus, dan Radio. Ancaman yang mungkin terjadi adalah mahalnya harga barang-barang elektronik yang dibutuhkan Laundry 
Bar seperti mesin cuci, setrika, dan lainnya. Terjadi gangguan pada mesin cuci yang telah dimiliki dan membutuhkan biaya maintenance. Selain, itu kondisi cuaca yang tidak dapat diperkirakan seperti hujan pun dapat mengganggu aktivitas bisnis Laundry Bar.

Berdasarkan hal tersebut dirasa perlu bagi Laundry Bar untuk menambahkan mesin cuci dan pegawai untuk mengatasi masalah over order, cara lain yang dapat dilakukan adalah dengan memperbesar store atau membuat store lain sebagai cabang Laundry Bar untuk meningkatkan kapasitas produksi dan memperluas jangkauan pemasaran bisnis Laundry Bar. Selain itu, dengan adanya store cabang dirasa dapat meningkatkan efektifitas dari bisnis Laundry Bar. Selain menjadi lebih dekat dengan pelanggan, bisnis pun dapat tetap berjalan meskipun salah satu store mengalami gangguan sehingga proses operasional tetap dapat dilakukan. Selain itu, untuk mendukung dan meningkatkan kualitas dari layanan antar jemput dirasa perlu bagi Laundry Bar untuk membeli kendaraan box, selain untuk mengantisipasi permasalahan cuaca hujan yang tidak dapat diprediksi, kendaraan box juga meningkatkan kapasitas untuk mengangkut cucian pelanggan Laundry Bar.

\subsection{Key Activities}

Aktivitas utama suatu bisnis terdiri dari produksi, pemecahan masalah, dan promosi. Pada Laundry Bar aktivitas produksi bisnis tersebut terdiri dari kegiatan mencuci, mengeringkan, setrika, memberi pewangi, dan proses packing atau membungkus cucian yang telah selesai. Aktivitas pemecahan masalah pada bisnis Laundry Bar terlihat pada kegiatan bisnis tersebut dalam merespon keluhan dan komplain dari pelanggan Laundry Bar, dan aktivitas promosi pada Laundry Bar terlihat dari kegiatan promosi Laundry Bar melalui akun Line@ yang dimilikinya dan juga iklan melalui partner Telkom Hitz serta media sosial Facebook (Grup Forum Jual Beli Universitas Telkom). Selain itu, kegiatan antar jemput cucian juga termasuk aktivitas bisnis terkait jaringan layanan bisnis Laundry Bar.

Dengan adanya penambahan channel yang digunakan seperti media sosial untuk meningkatkan hubungan pelanggan dan juga website, aktivitas juga perlu ditambah. SDM yang khusus menangani bidang IT dan memiliki tugas dalam memegang kendali media sosial yang dimiliki dan juga website. Mulai dari menjawab pertanyaan pelanggan, mambalas komentar, memuat gambar, update informasi, dan aktivitas lainnya yang berhubungan dengan sistem teknologi informasi. Dengan melihat keadaan bisnis yang sedang berjalan saat ini, Bapak Yusuf sendiri selaku pemilik bisnis dan yang menjalankan bisnis dapat memegang kendali atas media sosial dan website itu sendiri di sela-sela waktu yang dimiliki, dengan demikian segala keluhan ataupun saran dapat langsung diterima dan dipertimbangkan. Selain itu, dalam rangka untuk meningkatkan kualitas layanan yang diberikan seperti yang diungkapkan pada elemen value proposition, aktivitas pengecekan kebersihan pakaian dapat dijalankan dan untuk efisiensi waktu hal tersebut dapat disatukan dengan aktivitas setrika pakaian, karena pada aktivitas ini pakaian dapat terlihat dan di cek satu per satu.

\subsection{Key Partners}

Mitra dari bisnis Laundry Bar adalah, Forti sebagai pemasok bahan chemical laundry, Zamzam Laundry sebagai mitra dalam mendukung layanan yang dimiliki Laundry Bar dalam mencuci karpet dan boneka, dan Telkom Hitz sebagai mitra media dalam melakukan iklan dan promosi. Jika dilihat dari tujuan Laundry Bar dalam menjalin kemitraan adalah untuk mengoptimalkan model bisnis Laundry Bar dan juga untuk memperoleh sumber daya yang dibutuhkan, dan jika dilihat berdasarkan bentuk kemitraan yang dilakukan oleh Laundry Bar hanya sebatas hubungan pembeli-pemasok saja.

Dengan adanya hasil evaluasi elemen value proposition pada Laundry Bar yang dirasa perlu untuk meningkatkan kualitas layanan sebagai kekuatan dalam menghadapi persaingan, salah satu cara yang dapat dilakukan adalah dengan menjalin kemitraan dengan pemasok bahan chemical laundry yang lebih berkualitas dibandingkan saat ini, selain itu untuk menambahkan layanan yang diberikan Laundry Bar juga dirasa perlu untuk menjalin kemitraan dengan bisnis laundry yang menyediakan layanan yang lebih beragam, seperti layanan cuci Helm karena terdapat kebutuhan akan layanan tersebut terlebih saat musim penghujan. Selain itu dengan melihat adanya ancaman jika hanya menjalin kemitraan dengan satu penyuplai saja, Laundry Bar juga perlu untuk memiliki pemasok setidaknya lebih dari satu untuk memenuhi kebutuhan bisnis, karena dengan memiliki beberapa pemasok akan mengurangi
JURNAL

MANAJEMEN

INDONESIA

Vol. 17 - No. 2

Agustus 2017

Gambar 2.

Business Model Canvas dan Hasil Evaluasi

Business Model Canvas

Laundry Bar

Sumber:

Hasil Olahan Penulis, 2015 


\section{JURNAL}

MANAJEMEN

INDONESIA

Vol. 17 - No. 2

Agustus 2017

risiko yang mungkin dihadapi oleh Laundry Bar jika pemasok yang dimilikinya mengalami gangguan atau hambatan dalam menyalurkan kebutuhan bisnis Laundry Bar.

\subsection{Cost Structure}

Biaya yang dikeluarkan oleh Laundry Bar dalam mengoperasikan model bisnisnya di antaranya adalah untuk biaya operasional yang terdiri dari biaya listrik, air, dan gas untuk mesin pengering yang dimiliki oleh Laundry Bar, serta gaji pegawai. Selain itu terdapat juga biaya untuk pembelian bahan chemical yang terdiri dari detergen, pelicin, serta pewangi. Laundry Bar dalam mengelola struktur biaya termasuk ke dalam kelas cost-driven dimana bisnis ini lebih fokus terhadap minimasi biaya untuk menciptakan struktur biaya yang paling murah.

Dengan melihat hasil evaluasi pada elemen-elemen lain business model canvas Laundry Bar yang dirasa perlu untuk meningkatkan kualitas layanan, maka Laundry Bar harus merubah cara mengelola struktur biaya ke dalam kelas value-driven agar nilai dan kualitas layanan bagi pelanggan Laundry Bar dapat dimaksimalkan. Untuk menanggulangi kelemahan dalam pemakaian gas LPG yang selama ini kurang efisien, kedepannya perlu dipertimbangkan untuk menata ulang atau memperbesar store yang dimiliki Laundry Bar untuk menyisakan satu ruangan agar dirubah menjadi ruangan pengering. Dengan kapasitas mesin pengering yang dimiliki yang mampu memanaskan satu ruangan untuk keperluan pengeringan cucian penggunaan LPG pun akan lebih efisien karena dalam proses pengeringan yang dilakukan kapasitasnya akan jauh lebih banyak dibandingkan saat ini.

\begin{tabular}{|c|c|c|c|c|}
\hline \multirow[t]{2}{*}{$\begin{array}{l}\text { Key Partners } \\
\text { - Forti (Laudry } \\
\text { Chemical Sup- } \\
\text { plier) } \\
\text { - Zamzam } \\
\text { Laundry } \\
\text { - Telkom Hitz } \\
\text { (Media Sosial) } \\
\text { Hasil Evaluasi } \\
\text { - Forti diganti } \\
\text { dengan New } \\
\text { Cleans } \\
\text { - Zamzam Laudry } \\
\text { digantikan } \\
\text { dengan Abang } \\
\text { Laundry } \\
\text { (menambahkan } \\
\text { pemasok lain sebagai } \\
\text { backup dari pemasok } \\
\text { utama) }\end{array}$} & $\begin{array}{l}\text { Key Activities } \\
\text { - Cuci, Setrika, } \\
\text { Pengeringan, } \\
\text { Memberikan } \\
\text { pewangi, dan } \\
\text { Packing } \\
\text { - Menyelesaikan } \\
\text { keluhan/ kom- } \\
\text { plain pelanggan } \\
\text { - Iklan dan pro- } \\
\text { mosi } \\
\text { Hasil Evaluasi } \\
\text { Menambah aktivitas } \\
\text { mengelola sistem } \\
\text { informasi yang } \\
\text { dimiliki (media sosial } \\
\text { \& website) }\end{array}$ & \multirow{2}{*}{$\begin{array}{l}\text { Value Proposition } \\
\text { - Cuci dan Setrika Pakaian, } \\
\text { - Sepatu, Boneka, Karpet. } \\
\text { Layanan antar dan jemput } \\
\text { cucian (Tanpa minimal } \\
\text { transaksi dan batasan } \\
\text { waktu) } \\
\text { - Memiliki beragam pilihan } \\
\text { jenis layanan dan promo } \\
\text { - Memberikan harga yang } \\
\text { bersaing. } \\
\text { - Memperlakukan beberapa } \\
\text { jenis pakaian secara khu- } \\
\text { sus sesuai permintaan } \\
\text { konsumen } \\
\text { Hasil Evaluasi } \\
\text { - Menyediakan layanan } \\
\text { cuci Helm } \\
\text { - Meningkatkan kualitas } \\
\text { layanan yang diberikan } \\
\text { Menerapkan sistem } \\
\text { voucher } \\
\text { Channels } \\
\text { - Store Laundry Bar } \\
\text { - Tenaga Penjualan (Lay- } \\
\text { anan antar jemput) } \\
\text { - Media sosial (Akun } \\
\text { Line@ Laundry Bar) } \\
\text { Hasil Evaluasi } \\
\text { - Membuat website } \\
\text { - Menjalin kerja sama } \\
\text { dengan penyedia kost } \\
\text { atau asrama }\end{array}$} & $\begin{array}{l}\text { Customer Relation- } \\
\text { ships } \\
\text { - Melayani komplain } \\
\text { maks. 2x24 jam } \\
\text { - Memberikan } \\
\text { penawaran dan } \\
\text { rekomendasi } \\
\text { layanan kepada } \\
\text { pelanggan } \\
\text { - Meminta review } \\
\text { dari pelanggan } \\
\text { Hasil Evaluasi } \\
\text { - Meningkatkan } \\
\text { fungsi member } \\
\text { - Menggunakan } \\
\text { lebih banyak } \\
\text { media sosial }\end{array}$ & \multirow[t]{2}{*}{$\begin{array}{l}\text { Customer Seg- } \\
\text { ments } \\
\text { Masyarakat Umum } \\
\text { (Keluarga dan } \\
\text { Mahasiswa) di } \\
\text { lingkungan Uni- } \\
\text { versitas Telkom } \\
\text { Hasil Evaluasi } \\
\text { Lebih fokus } \\
\text { terhadap segmen } \\
\text { mahasiswa Univer- } \\
\text { sitas Telkom. }\end{array}$} \\
\hline & $\begin{array}{l}\text { Key Resources } \\
\text { - } \text { Bangunan Store } \\
\text { - Laundry Bar } \\
\text { - } 2 \text { buah Mesin } \\
\text { Cuci } \\
\text { - Alat Setrika } \\
\text { - } \text { Alat pengering } \\
\text { - Rak pakaian } \\
\text { - Jemuran/ gantun- } \\
\text { gan pakaian } \\
\text { - Kas usaha } \\
\text { - Pegawai (2 } \\
\text { orang) } \\
\text { Hasil Evaluasi } \\
\text { - Memperluas dan } \\
\text { menambah store } \\
\text { - Menambah mesin } \\
\text { cuci dan pegawai. } \\
\text { - Membeli kenda- } \\
\text { raan box untuk } \\
\text { layanan antar } \\
\text { jemput. }\end{array}$ & & & \\
\hline \multicolumn{3}{|c|}{$\begin{array}{l}\text { Cost Structure (Cost-driven) } \\
\text { - Biaya operasional (Listrik, air, gaji pegawai) } \\
\text { - } \text { Bahan chemical (Detergen, pelican, pewangi) } \\
\text { - } \quad \text { Gas (Untuk mesin pengering) } \\
\text { Hasil Evaluasi } \\
\text { Merubah model cost-driven menjadi value-driven. }\end{array}$} & \multicolumn{2}{|c|}{$\begin{array}{l}\text { Revenue Streams } \\
\text { - Cuci dan Setrika Pakaian, } \\
\text { Sepatu, Karpet dan Boneka } \\
\text { - Membership } \\
\text { Hasil Evaluasi } \\
\text { Terjadinya aliran pendapa- } \\
\text { tan berulang melalui sistem } \\
\text { voucher. }\end{array}$} \\
\hline
\end{tabular}




\section{Kesimpulan}

Laundry Bar pada umumnya telah menerapkan sebuah model bisnis yang memenuhi kesembilan unsur penting seperti yang dijelaskan pada teori Business Model Canvas, sehingga dapat dikatakan bahwa pada dasarnya unsur-unsur yang harus dipenuhi dan diterapkan terkait business model canvas Laundry Bar untuk mengembangkan bisnisnya telah dijalankan.

Setelah dilakukan evaluasi terhadap model bisnis Laundry Bar dengan menggunakan analisis SWOT yang telah dijabarkan pada penjelasan pada bab 4, maka terdapat beberapa hal yang dirasa perlu untuk dievaluasi terkait model bisnis yang dijalankan Laundry Bar, di antaranya adalah lebih mempersempit target pasar bisnis Laundry Bar menjadi mahasiswa Universitas Telkom saja, merubah serta menambah mitra bisnis yang ada pada Laundry Bar dan menambahkan saluran pemasaran serta sumber daya Laundry Bar untuk mendukung peningkatan kualitas layanan yang akan dilakukan oleh Laundry Bar demi terciptanya citra merek Laundry Bar pada konsumennya. Hasil evaluasi yang telah dilakukan pun merubah cara pengelolaan biaya pada Laundry Bar yang semula bersifat cost-driven menjadi valuedriven.

Penelitian ini hanya menggunakan metode penelitian kualitatif saja sehingga diharapkan bagi peneliti lainnya yang tertarik untuk membuat penelitian pada bidang serupa, disarankan untuk menggunakan teori penyusunan strategi yang lebih kompleks dan lengkap dengan menggunakan metode penelitian kuantitatif atau metode campuran (kualitatif dan kuantitatif) sehingga rekomendasi strategi yang dihasilkan dari penelitian yang dilakukan dapat lebih diandalkan.

\section{Daftar Pustaka}

Coes, Bastian. (2014). Critically Assessing The Strengths and Limitations of The Business Model Canvas. Disertasi Master Business Administration Enschede: University of Twente.

Dudin, Mikhail N et al. (2015). The innovative Business Model Canvas in the System of Effective Budgeting. Asian Social Science, Vol.II, 290-296. Toronto: Canadian Center of Science and Education.

Hernama \& Rooshwan Budi Utomo. (2015). Analisis Lingkungan Usaha Model Bisnis Kanvas Pada Usaha Batik Ciwaringin Cirebon. Syariah Paper Accounting FEB UMS, 594-606. Surakarta: Publikasi Ilmiah UMS.

Indrawati. (2015). Metode Penelitian Manajemen dan Bisnis: Konvergensi Teknologi Komunikasi dan Informasi. Bandung: Refika Aditama.

Kosaso, Velicia Magdalena. (2015). Analisis dan Evaluasi Model Bisnis pada Pantai Seafood Restaurant dengan Pendekatan Business Model Canvas. Jurnal Manajemen Bisnis, Vol.III, 314-323. Surabaya: Agora.

Kotler, Philip \& Kevin Lane Keller. (2009). Manajemen Pemasaran (Edisi 13, Jilid 1). Jakarta: Erlangga.

Lund, Morten \& Christian Nielsen. (2014). The Evolution of Network-based Business Models Illustrated Through the Case Study of an Entrepreneurship Project. Journal of Business Models Vol.II, 105-121. Aalborg: Aalborg University Press.

Maghfirah et al. (2014). E-Business Analysis of Garut University (UNIGA) Using the Business Model Canvas. International Journal of Science and Research Vol.III, 529-534. Nagpur: IJSR.

Osterwalder, Alexander \& Yves Pigneur. (2009). Business Model Generation: A Handbook for Visionaries, Game Changers, and Challengers. New Jersey: John Wiley \& Sons, Inc.

Pearce II, John A. \& Richard B. Robinson, Jr. (2008). Manajemen Strategis: Formulasi, Implementasi, dan Pengendalian (Edisi 10, Buku 1). Jakarta: Salemba Empat. 
Perkumpulan Untuk Peningkatan Usaha Kecil. 2012. Pengembangan Model Bisnis Bagi UKM. [Online]. Tersedia: http://www.pupuk.or.id/index.php/component/k2/item/10pengembangan-model-bisnis-bagi-ukm [18 September 2015].

JURNAL

MANAJEMEN

INDONESIA

Satori, Djam'an \& Aan Komariah. (2011). Metodologi Penelitian Kualitatif. Bandung: Alfabeta

Vol. 17 - No. 2

Agustus 2017

Sugiyono. (2014). Metode Penelitian Kuantitatif Kualitatif dan R\&D. Bandung: Alfabeta. 